\title{
Correlation and Path-Coefficient Estimates of Yield and Yield Component Traits in Rice Fallow Blackgram [Vigna mungo (L.) Hepper]
}

\author{
Hari Ram Kumar Bandi ${ }^{1 *}$, K. Nagendra Rao ${ }^{1}$, K. Vamsi Krishna ${ }^{2}$ and K. Srinivasulu ${ }^{3}$ \\ ${ }^{1}$ Department of Genetics and Plant Breeding, ANGRAU-Guntur-522509, India \\ ${ }^{2}$ Department of Genetics and Plant Breeding, Agricultural College Bapatla-Guntur, India \\ ${ }^{3}$ Department of Agronomy, ANGRAU-Guntur-522509, India
}

*Corresponding author

\section{A B S T R A C T}

\begin{tabular}{|l|}
\hline Key w o r d s \\
Association, Path \\
analysis, Yield \\
parameters and \\
Blackgram
\end{tabular}

Studies on thirty six blackgram genotypes for the association and path analysis, revealed that, the genotypic correlations were in general higher than the phenotypic correlations and thus suggested that the observed relationships among the characters were due to genetic causes. The traits, number of clusters per plant, number of pods per plant, number of seeds per pod and 100 seed weight were found to possess positive significant association in desirable direction with grain yield per plant either at both genotypic and phenotypic levels. Further, it was also observed that days to $50 \%$ flowering and days to maturity were found to be negative and significantly correlated with grain yield per plant. Path analysis showed the true relationship of plant height, number of pods per plant, pod length, number of seeds per pod and 100 seed weight by establishing significant positive association and positive direct effect on grain yield per plant, whereas days to maturity showed true relationship by establishing significant negative association and negative direct effect on grain yield per plant, the residual effect at phenotypic level was 0.203 indicating that the characters included in the present investigation are contributing more than 79.70 per cent of variability pertaining the dependent variable i.e., grain yield per plant.

\section{Introduction}

Blackgram (Vigna mungo (L.) Hepper) was popularly known as urdbean, urid or mash. In India it is cultivated in 32.60 lakh ha producing 17.60 lakh tons with an average productivity of $534 \mathrm{~kg} / \mathrm{ha}$ (Source: Project coordinates (MULLaRP) Report, IIPR, Kanpur 2011-2012). In Andhra Pradesh blackgram is traditionally cultivated as a rabi pulse crop under rice fallows mainly along the coastal areas, in an area of 5 lakh ha with a production and productivity of 3.29 lakh tons and 728 $\mathrm{kg} / \mathrm{ha}$, respectively during 2016-17. Blackgram consists of good nutritional values of high seed protein (25-26\%), carbohydrates $(60 \%)$, fat $(1.5 \%)$, minerals, amino acids and vitamins. Hence, it is usually known as "poor man's meat" particularly in the vegetarian population of the Indian subcontinent (Chubatemsu and Malini, 2017). As yield is the resultant product of various morphological, physiological and biological components. It is essential to understand the 
genetic architecture and nature of gene action governing yield and its component traits of increase the yield per unit area. Studies on the phenotypic and genotypic correlation of the yield components and their contribution to the yield in path analysis provide information to design appropriate breeding methods towards the improvement the crop. In view of these, thirty six blackgram genotypes were studied for their component characters to determine the degree of correlation and their direct and indirect effect on yield.

\section{Materials and Methods}

Thirty six blackgram (Vigna mungo (L.) Hepper) genotypes of diverse origin were sown in a Randomized Block Design in three replications, each of 4 rows of 4 meters length with spacing of $30 \mathrm{~cm} \times 10 \mathrm{~cm}$ at Agricultural Research Station, Ghantasala, Krishna District, during Rabi, 2016-17. Observations were recorded for 10 quantitative characters viz., days to $50 \%$ flowering, days to maturity, plant height $(\mathrm{cm})$, number of branches per plant, number of clusters per plant, number of pods per plant, pod length $(\mathrm{cm})$, number of seeds per pod, 100 seed weight $(\mathrm{g})$ and grain yield per plant $(\mathrm{g})$. Data were recorded from five randomly selected plants from each genotype per replication and the average was taken for analysis. All the recommended package of practices was followed to raise a good crop. Standard statistical procedures were used for the analysis of correlation coefficient values(r) at genotypic and phenotypic levels by Johnson et al., (1955a) and described by Singh and Choudhary (1985). Path coefficient analysis was utilized to partition the phenotypic and genotypic correlation coefficient into the direct effects and indirect effects along with residual effects. The analysis was carried out as per the equation suggested by Dewey and Lu (1959) originally proposed by Wright (1921) and described by Singh and Choudhary (1985).

\section{Results and Discussion}

\section{Correlation}

Correlation coefficient is a statistical measure, which is used to find out the degree and direction of relationship between two or more variables. The results revealed that genotypic correlations were in general higher than the phenotypic correlations and thus suggested that the observed relationships among the characters were due to genetic causes. The values of phenotypic and genotypic correlation coefficient among yield and it attributes are presented in Table 1 and 2 .

\section{Correlation with grain yield per plant}

In present investigation, number of clusters per plant, number of pods per plant, number of seeds per pod and 100 seed weight showed positive significant associated with seed yield per plant both at phenotypic and genotypic levels. Whereas, days to $50 \%$ flowering, days to maturity exhibited negative and significant association with grain yield per plant. While, plant height showed positively non-significant association at phenotypic level and negatively non-significant association at genotypic level. Positive and non-significant correlation was observed between pod length per plant and grain yield per plant at both phenotypic and genotypic level. Number of branches per plant exhibited negative and non-significant association with grain yield per plant at both phenotypic and genotypic levels, respectively. These results are in accordance with findings of Vijay Kumar et al., (2015), Reena et al., (2016) and Sunayana et al., (2017).

\section{Correlation among the yield contributing characters}

Days to $50 \%$ flowering showed positive and significant correlation with days to maturity and plant height. 
.1 Phenotypic correlation among yield and yield contributing characters in rice fallow blackgram [Vigna mungo (L.) Hepper]

\begin{tabular}{|c|c|c|c|c|c|c|c|c|c|c|c|c|}
\hline $\begin{array}{l}\text { S. } \\
\text { No }\end{array}$ & Characters & & $\begin{array}{l}\text { Days to } 50 \% \\
\text { flowering }\end{array}$ & $\begin{array}{l}\text { Days to } \\
\text { maturity }\end{array}$ & $\begin{array}{c}\text { Plant } \\
\text { height } \\
(\mathrm{cm})\end{array}$ & $\begin{array}{l}\text { No. of } \\
\text { branches } \\
\text { per plant }\end{array}$ & $\begin{array}{l}\text { No. of } \\
\text { clusters per } \\
\text { plant }\end{array}$ & $\begin{array}{l}\text { No. of pods } \\
\text { per plant }\end{array}$ & $\begin{array}{l}\text { Pod } \\
\text { length } \\
\text { (cm) }\end{array}$ & $\begin{array}{l}\text { No. of seed } \\
\text { per pod }\end{array}$ & $\begin{array}{c}100 \text { Seed } \\
\text { weight (g) }\end{array}$ & $\begin{array}{c}\text { Grain } \\
\text { yield per } \\
\text { plant (gm) }\end{array}$ \\
\hline 1 & Days to $50 \%$ flowering & $r_{p}$ & 1.000 & $0.923 * *$ & $0.369 * *$ & 0.019 & $-0.391 * *$ & $-0.446 * *$ & -0.085 & $-0.326 * *$ & $0.276^{*}$ & $-0.268^{*}$ \\
\hline 2 & Days to maturity & $r_{p}$ & & 1.000 & $0.368 * *$ & 0.027 & $-0.367 * *$ & $-0.418 * *$ & -0.095 & $-0.301 *$ & $0.301 *$ & $-0.233 *$ \\
\hline 3 & Plant height $(\mathrm{cm})$ & $r_{p}$ & & & 1.000 & 0.180 & -0.177 & -0.176 & 0.132 & -0.096 & 0.219 & 0.007 \\
\hline 4 & No.of branches per plant & $r_{p}$ & & & & 1.000 & 0.086 & 0.039 & 0.115 & -0.114 & -0.063 & -0.019 \\
\hline 5 & No. of clusters per plant & $r_{p}$ & & & & & 1.000 & $0.766^{* *}$ & -0.054 & $0.473 * *$ & -0.120 & $0.559 * *$ \\
\hline 6 & No.of pods per plant & $r_{p}$ & & & & & & 1.000 & -0.020 & $0.623 * *$ & -0.002 & $0.836^{* *}$ \\
\hline 7 & Pod length (cm) & $r_{p}$ & & & & & & & 1.000 & 0.011 & 0.017 & 0.037 \\
\hline 8 & No.of seed per pod & $r_{p}$ & & & & & & & & 1.000 & 0.099 & $0.755^{* *}$ \\
\hline 9 & 100 Seed weight (g) & $r_{p}$ & & & & & & & & & 1.000 & $0.436^{* *}$ \\
\hline 10 & Grain yield per plant (gm) & $r_{p}$ & & & & & & & & & & 1.000 \\
\hline
\end{tabular}

Table.2 Genotypic correlation among yield and yield contributing characters in rice fallow blackgram [Vigna mungo (L.) Hepper]

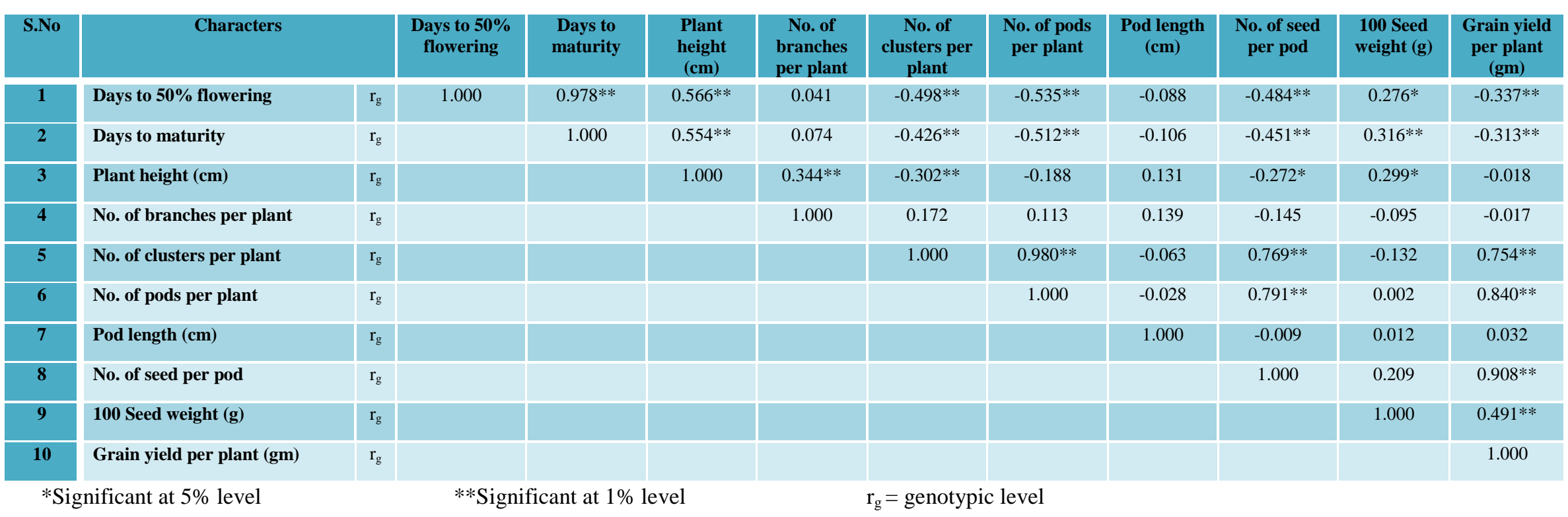


Table.3 Phenotypic direct and indirect effects of different yield contributing characters on grain yield per plant in rice fallow blackgram (Vigna mungo (L.) Hepper)

\begin{tabular}{|c|c|c|c|c|c|c|c|c|c|c|}
\hline S.No & Characters & $\begin{array}{c}\text { Days to } 50 \% \\
\text { flowering }\end{array}$ & $\begin{array}{l}\text { Days to } \\
\text { maturity }\end{array}$ & $\begin{array}{l}\text { Plant height } \\
\text { (cm) }\end{array}$ & $\begin{array}{l}\text { No. of branches } \\
\text { per plant }\end{array}$ & $\begin{array}{c}\text { No. of clusters } \\
\text { per plant }\end{array}$ & $\begin{array}{c}\text { No. of pods } \\
\text { per plant }\end{array}$ & $\begin{array}{l}\text { Pod length } \\
\text { (cm) }\end{array}$ & $\begin{array}{c}\text { No. of seed } \\
\text { per pod }\end{array}$ & $\begin{array}{c}100 \text { Seed } \\
\text { weight }(\mathrm{g})\end{array}$ \\
\hline 1 & Days to $50 \%$ flowering & 0.000 & 0.000 & 0.000 & 0.000 & 0.000 & 0.000 & 0.000 & 0.000 & 0.000 \\
\hline 2 & Days to maturity & -0.006 & -0.006 & -0.002 & 0.000 & 0.002 & 0.003 & 0.001 & 0.002 & -0.002 \\
\hline 3 & Plant height (cm) & 0.023 & 0.023 & 0.062 & 0.011 & -0.011 & -0.011 & 0.008 & -0.006 & 0.014 \\
\hline 4 & No. of branches per plant & 0.000 & 0.000 & 0.001 & 0.006 & 0.001 & 0.000 & 0.001 & -0.001 & 0.000 \\
\hline 5 & No. of clusters per plant & 0.030 & 0.029 & 0.014 & -0.007 & -0.078 & -0.059 & 0.004 & -0.037 & 0.009 \\
\hline 6 & No. of pods per plant & -0.315 & -0.296 & -0.125 & 0.027 & 0.541 & 0.707 & -0.014 & 0.440 & -0.001 \\
\hline 7 & Pod length $(\mathrm{cm})$ & -0.002 & -0.003 & 0.004 & 0.003 & -0.002 & -0.001 & 0.027 & 0.000 & 0.000 \\
\hline 8 & No. of seed per pod & -0.104 & -0.096 & -0.031 & -0.036 & 0.151 & 0.198 & 0.004 & 0.319 & 0.032 \\
\hline 9 & 100 Seed weight (g) & 0.106 & 0.116 & 0.084 & -0.024 & -0.046 & -0.001 & 0.006 & 0.038 & 0.384 \\
\hline 10 & Grain yield per plant (gm) & $-0.268^{*}$ & $-0.233 *$ & 0.007 & -0.019 & $0.559 * *$ & $0.836 * *$ & 0.037 & $0.755 * *$ & $0.436 * *$ \\
\hline
\end{tabular}

Fig.1 Phenotypic direct and indirect effects of different yield contributing characters on grain yield per plant in rice fallow blackgram [Vigna mungo (L.) Hepper]

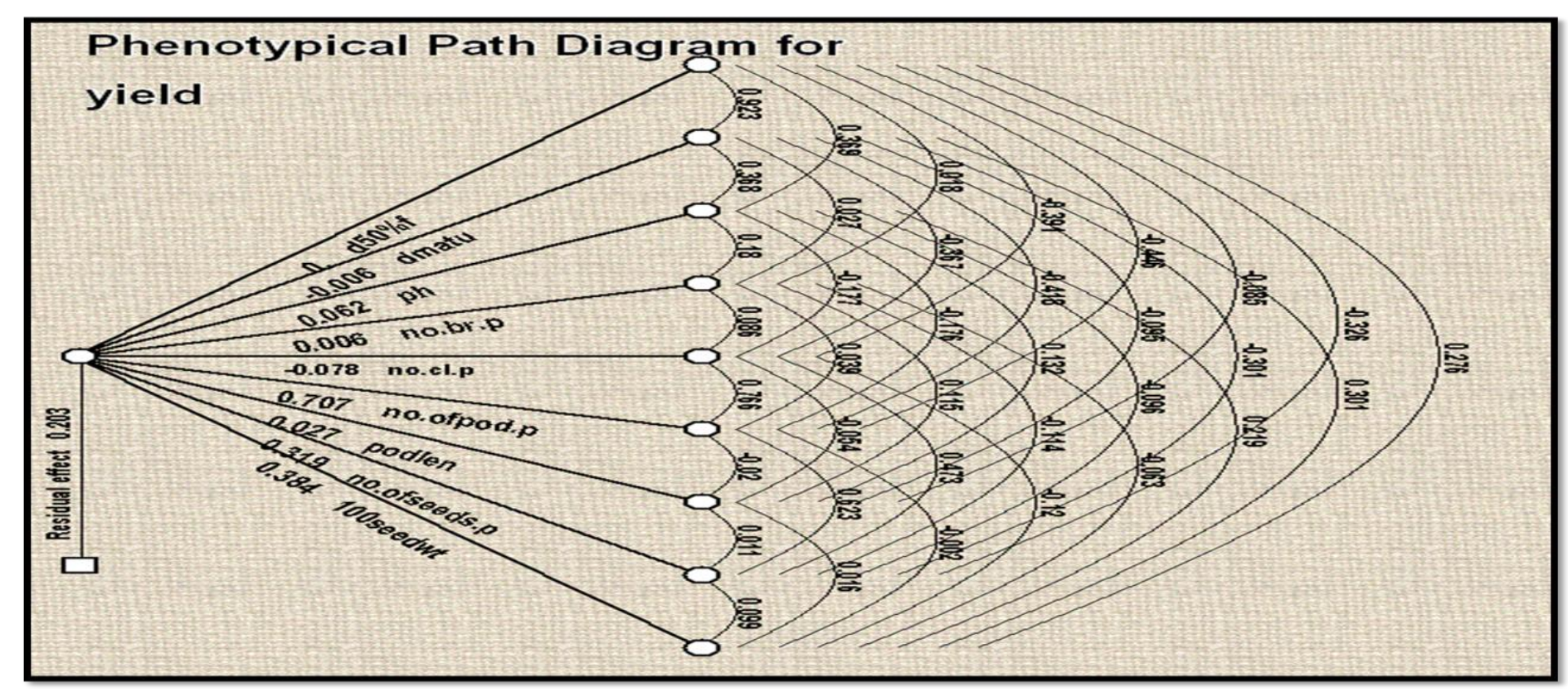


Whereas, positive and non-significant association with number of branches per plant at both phenotypic and genotypic levels. Negative and significant correlation with number of clusters per plant, number of pods per plant, number of seeds per pod and negative and non-significant association with pod length both at phenotypic and genotypic levels, respectively. Days to maturity established positive significant interrelationship with plant height and 100 seed weight.

Positive and non-significant association with number of branches per plant both at phenotypic and genotypic levels, respectively. It showed negative and significant correlation with number of clusters per plant, number of pods per plant and number of seeds per pod and negative and non-significant correlation with pod length at both phenotypic and genotypic levels, respectively.

Plant height exhibited positive significant association with number of branches per plant and number 100 seed weight at genotypic level. Positive and non-significant with number of branches per plant at phenotypic level, pod length both at phenotypic and genotypic level, respectively and 100 seed weight at phenotypic level.

It also showed negative significant association with number of clusters per plant at phenotypic level, number of pods per plant, at both phenotypic and genotypic level, respectively and number of seeds per pod at phenotypic level. Positive and non-significant correlation was established among number of branches per plant with number of clusters per plant, number of pods per plant and pod length both at phenotypic and genotypic levels. Whereas, negative non-significant association was observed with number of seeds per pod and 100 seed weight both at phenotypic and genotypic levels.
Number of clusters per plant showed positive significant inter-relationship with number of pods per plant and number of seeds per pod at phenotypic and genotypic levels, respectively. However, negative non-significant association was observed with pod length and 100 seed weight at both phenotypic and genotypic levels. Number of pods per plant established positive significant association with number of seeds per pod at both phenotypic and genotypic levels. Positive non-significant correlation with 100 seed weight at genotypic level. Negative non-significant association with pod length at phenotypic and genotypic level and 100 seed weight at phenotypic level.

Pod length exhibits positive non-significant association with number seeds per pod at phenotypic level and 100 seed weight at both phenotypic and genotypic levels. While, negative non-significant association with number of seeds per pod at genotypic level. Number of seeds per pod showed positive non-significant association with 100 seed weight both at phenotypic and genotypic levels.

\section{Path analysis}

Path analysis revealed that positive direct effects with positive correlation on grain yield was observed for the characters viz., plant height, number of pods per plant, pod length, number of seeds per pod and 100 seed weight. Whereas days to maturity showed true relationship by establishing significant negative association and negative direct effect on grain yield per plant (Table 3 and Fig. 1).

In plant breeding it is very difficult to have complete knowledge of all component traits of yield. The residual effect permits precise explanation about the pattern of interaction of other possible components of yield i.e., residual effect measures the role of the possible independent variables which were 
not included in the study on the dependent variable. In the present study, the residual effect at phenotypic level was 0.203 indicating that the characters included in the present investigation are contributing more than 79.70 per cent of variability pertaining the dependent variable i.e., grain yield per plant (Table 3 and Fig. 1).

Considering the nature and magnitude of character association and their direct and indirect effects, it can be inferred that simultaneous improvement of grain yield per plant is possible through manifestation of plant height, number of pods per plant, pod length, number of seeds per pod and 100 seed weight.

\section{References}

Chubatemsu Ozukum and Malini Barthakur Sharma. 2017. Variability among Urdbean (Vigna mungo L. Hepper) for yield and yield components. International Journal of Research and Innovation in Applied Sciences. 2 (4): 26-28.

Dewey, O.R and Lu, K.H. 1959. A correlation and path coefficient analysis of components of crested wheat grass seed production. Agronomy Journal. 57: 515518.
Johnson, H.W., Robinson, H.F., Comstock, R E. 1955.Genotypic and phenotypic correlations in pigeonpea and their implications in selection. Agronomy Journal. 47: 477-483

Lukoki, L., Marechal, R and Otoul, E. 1980. The wild ancestors of the cultivated beans $V$. radiata and $V$. mungo. Bulletin $d u$ Jardin Botanique National de Belgique. 28: 23- 30.

Reena Mehra, Tikle, A.N., Ashok Saxena., Ashok Munjal., Rekhakhandia and Mahipal Singh. 2016. Correlation, pathcoefficient and genetic diversity in Blackgram [Vigina mungo (L) Hepper] International Research Journal of Plant Science. 7 (1): 001-011.

Sunayana, Punia, M.S and Rajesh Yadav. 2017 Relationship and Genetic Variability of Seed Yield and MorphoPhysiological Traits in Mungbean (Vigna radiata (L.) Wilczek). International Journal of Pure \& Applied Bioscience. 5 (1): 543-551.

Vijay Kumar, G., Vanaja, M., Sathish, P., Vagheera, $\mathrm{P}$ and Jyothi Lakhsmi, N. 2015. Correlation analysis for quantitative traits in blackgram (Vigna mungo (L.) Hepper) in different seasons. International Journal of Scientific and Research Publications. 5 (4): $1-10$.

\section{How to cite this article:}

Hari Ram Kumar Bandi, K. Nagendra Rao, K. Vamsi Krishna and Srinivasulu, K. 2018. Correlation and Path-Coefficient Estimates of Yield and Yield Component Traits in Rice Fallow Blackgram (Vigna mungo (L.) Hepper). Int.J.Curr.Microbiol.App.Sci. 7(03): 33043309. doi: https://doi.org/10.20546/ijcmas.2018.703.380 